\title{
Real Estate Assets for Social Impact: The Case of the Public Company for Social Services "ASP City of Bologna"
}

\author{
Angela S. Pavesi, Andrea Ciaramella, Marzia Morena and Genny Cia
}

\begin{abstract}
In 2016, the Public Company for Social Services of the Municipality of Bologna "ASP City of Bologna" requires the ABC Department to analyze its huge real estate portfolio with the aim to identify efficiency strategies to free up resources to be reinvested in the offer of personal social services. Corporate governance sets up its strategy by coherently matching: the statutory values, the corporate mission and the growing need to respond to the needs expressed by the community in terms of providing personal services. The collaboration found strong foundations of understanding in the intention to pursue the mission of general social interest with environmental and economic sustainability, in a research path that made explicit the values of transparency and accountability of the Company. On the one hand, the research outlined the levers for making management, resources and processes more efficient, and on the other, strategies for enhancing assets in a social and circular economy perspective (see Bilancio Sociale ASP 2017).
\end{abstract}

Keywords Evaluation and enhancement of real estate assets - Management optimization of public company $\cdot$ Real estate infrastructure for personal services • Models for the management of real estate assets - Social economy and circular economy

\footnotetext{
${ }^{1}$ According to the ASP Statute, the Shareholders' Meeting monitors and controls the ASP's activity and performs various functions including: "[...] defines the general guidelines of the ASP; approves the transformation of the assets from unavailable to available, as well as the disposals of available assets [...]."
}

A. S. Pavesi ( $\square) \cdot$ A. Ciaramella $\cdot$ M. Morena $\cdot$ G. Cia

Architecture, Built Environment and Construction Engineering-ABC Department, Politecnico di Milano, Milan, Italy

e-mail: angela.pavesi@polimi.it 


\section{Introduction}

In October 2016, the Public Company for Social Services of the Municipality of Bologna_ASP Città di Bologna (hereinafter “ASP")—_brings to the Shareholders Meeting ${ }^{1}$ the proposal of a research path aimed to evaluate, analyze its own available assets and its management model in order to identify strategies/opportunities to make the assets profitability more efficient and to free up resources to increase the supply of services to citizens. The proposal of a research project with these aims immediately outlines the highly strategic view of ASP governance ${ }^{2}$ that challenges its model to best adhere to its statutory mission. Subsequently, ASP identifies in ABC Department of Politecnico di Milano the qualified partner with which to start the path ${ }^{3}$, and, right from the start, the collaboration finds very strong bases of understanding precisely in that proactive intentionality with which, not only governance, but all the manpower involved in the various functions, pursuing the aim of sustainable innovation, in a virtuous combination that distinguishes the Company for transparency and accountability.

Starting from these assumptions and in pursuing the research aims, the ABC Department started a path of support for the Company lasting over a year, adapting results to progressive requests, up to the elaboration of a final research report which clearly outlines:

- levers for improving the management model and optimizing the Company's ${ }^{4}$ resources and processes;

- value of available real estate portfolios;

- enhancement strategies for strategic porfolio;

- strategies for management and energy efficiency;

- strategies for innovation of welfare models (services provided).

Furthermore, some experiments have been started on specific assets of the Company.

\footnotetext{
${ }^{2}$ Gianluca Borghi, formerly Sole Director and Elisabetta Scoccati, formerly General Manager of ASP.

${ }^{3}$ December 2016: entrusted to the ABC Department of the research project for the enhancement of the real estate assets of ASP Città di Bologna through the study of an adequate management model with respect to the aims of the Entity. "Scientific coordinator: professor A. S. Pavesi. Research group: professor A. Ciaramella and M. Morena and ingg. G. Cia and M. Gechelin."

${ }^{4}$ by Asset Management and Corporate Real Estate Companies benchmarks.
} 


\section{The ASP Città di Bologna Mission and Its Real Estate Portfolio as a Social Infrastructure for a Resilient City}

ASP Città di Bologna is the Public Company for Social Services of Bologna set up by resolution of the Council of the Emilia-Romagna Region no. 2078 of 12/23/2013 following the merger of the Public Company of Poveri Vergognosi, the Public Company of Servizi alla Persona Giovanni XXIII, and the Public Company of IriDes.

ASP is a non-economic public entity governed by regional law, with legal status governed by public law, statutory, managerial, patrimonial, accounting and financial autonomy, within the framework of rules and principles established by regional law and regional indications. It is a non-profit organization. The ASP partners are the Municipality of Bologna (97\%), the Metropolitan City of Bologna (2\%), and Fondazione Carisbo (1\%).

Art. 4 of the Statute shows the mission of the Company: "ASP has as its purpose management and provision of social, social-health services to elderly, adult and minor persons who are in conditions of difficulty, hardship, disability or non selfsufficiency, according to the different needs defined by local programming".

To pursue its statutory mission, ASP owns heterogeneous real estate portfolio, deriving from bequests and inheritances and is distinguished in available or unavailable assets depending on whether it is alienable or not. This subdivision comes from the, i.e., art. 5 paragraph 1 of the Regional Law 12/2013 and provides:

- buildings used to pursue statutory and welfare purposes, i.e. unavailable assets;

- assets which, in consideration of their valuable characteristics, or because they are susceptible to entrepreneurial use, are destined to income and to support the provision of services of social initiatives, i.e., assets available for income;

- buildings used for: housing needs, social activities, activities carried out by nonprofit entities, i.e., assets available for housing needs;

- agricultural assets destined to favor youth entrepreneurship or made available to non-profit entities that perform social recovery and assistance purposes for weak subjects, i.e., social agricultural assets;

- and historical and artistic heritage.

The assets characteristics have been made explicit in a quantitative and qualitative desktop analysis carried out by the research group alongside ASP, which was subsequently optimized in properties evaluation phase.

From a quantitative point of view and according to the survey concluded in October 2017 (see Table 1), the ASP real estate portfolios consist of $1462^{5}$ real estate unitslocated mainly in the city of Bologna, about 2000 ha of agricultural land and about 130 farm buildings - located in the province of Bologna. ${ }^{6}$

\footnotetext{
${ }^{5}$ Dynamic data.

${ }^{6}$ The research group developed a survey of the rural portfolio, identifying its main characteristics. These cards represent the first step in defining ad hoc valorization strategies. The theme of rural portfoliola des can be the subject of in-depth analysis of a phase 2 of the research that consists in the census and analysis of best practices in the field of valorization of rural buildings, in the
} 
Table 1 Recognition of ASP real estate portfolio in October 2017 (source Research report)

\begin{tabular}{l|c|c}
\hline Category & $\begin{array}{l}\text { N. property } \\
\text { January } 2017\end{array}$ & $\begin{array}{l}\text { N. property } \\
\text { October 2017 }\end{array}$ \\
\hline Houses & 665 & 665 \\
\hline Offices & 67 & 67 \\
\hline Care facility & $\mathbf{2 2}$ & $\mathbf{2 3}$ \\
\hline Public offices & 2 & 2 \\
\hline $\begin{array}{l}\text { School and } \\
\text { laboratories }\end{array}$ & $\mathbf{2}$ & $\mathbf{3}$ \\
\hline $\begin{array}{l}\text { Libraries, } \\
\text { museums, and } \\
\text { galleries }\end{array}$ & 1 & 1 \\
\hline Shops & 50 & 50 \\
\hline Stores & 94 & 94 \\
\hline Laboratories & 11 & 11 \\
\hline Sports facilities & 2 & 2 \\
\hline Garages & $\mathbf{2 5 6}$ & $\mathbf{3 3 4}$ \\
\hline $\begin{array}{l}\text { Closed and opened } \\
\text { roofs }\end{array}$ & 4 & 4 \\
\hline Factory & 14 & 14 \\
\hline Hotels & 2 & 2 \\
\hline Theater, cinema & 1 & 132 \\
\hline $\begin{array}{l}\text { Agricultural } \\
\text { buildings }\end{array}$ & 136 & \\
\hline $\begin{array}{l}\text { Religious } \\
\text { buildings }\end{array}$ & 2 & 252 \\
\hline Other & 1386 & \\
\hline Total & & \\
\hline & & 14 \\
\hline
\end{tabular}

As mentioned, a part of the work carried out by the ABC Department consisted in rationalization of real estate database of ASP, by a desktop work on the spreadsheet that represented the IT management system used.

In the spreadsheet, each row corresponded a real estate unit identified through land register reference and in which were reported data of different nature: cadastral, administrative, economic, financial, and technical.

This work was a preliminary step to the subsequent phases of the project, highlighting areas of potential improvement, including:

- identify the most suitable management system to make data management more efficient, based on need to enhance real estate assets;

identification and analysis of the main tools and in the definition of the strategy more suitable for ASP. 
- define Quality plans for database management (definition of data entry, updating processes, etc.);

- carry out technical and administrative due diligence for buildings not yet surveyed or for which a valorization strategy has been defined;

- establish plans and programs for building and plant maintenance (Maintenance and Energy Management);

- consolidate technical and operational skills, and managerial ones.

The active management of real estate assets is crucial if we manage to adequately monitor information and time. It is only through knowledge that it is possible to define lines of action, plan interventions, deliberate, and take decisions. The preliminary analysis of assets, aimed at understanding the characteristics of the properties, lays the foundations for strategic management phase (Ciaramella 2016).

\section{Survey and Scenario: Clustering and Evaluation of Real Estate Assets}

The choice of the most appropriate valorization strategies cannot be separated from the mission of Institution, the role that single asset plays in the core business and real estate value both as balance sheet value and market value. Asset management should focus on two levels of performance: the increase in revenues and the increase in profitability (Burns 2002), in which the quantification of both a reduction in expenses, but also, a more efficient use of resources available, in order to maximize business purposes. According to Huffman (2003), the management strategies of real estate derive from the set of corporate strategies.

Based on these statements and thanks to the highly strategic view of ASP governance, an assessment of the most probable market value of the Company's available assets was necessary.

The Client, with the support of the research group, made a selection of the assets available which did not play a key role in the provision of services and in pursuit of the corporate mission but could have an attractiveness toward the market and allow new resources to be introduced in order to improve the offer of services.

As better outlined in the social balance (2017), ASP conceives the management of assets "according to criteria of efficiency, transparency and fairness, has the objective of enhancing the available assets, both real estate and agricultural, to generate resources to be allocated to citizen welfare. The action of optimization and effectiveness is expressed through recovery of arrears, maximization of profits also resulting from actions of organizational rationalization and transparency in the leasing process". The asset management perspective is therefore not attributable to pure economic efficiency, but to sustain, through the profitability of the assets, the costs of the citizen welfare system.

Following the patrimony survey, the Client and the ABC group selected the real estate units by linking them to homogeneous clusters by use, location, and in-depth 
assessment levels, on the basis of which the public tender was drawn up and the technical specifications for the selection of the most suitable market subject to perform this activity. ${ }^{7}$ Scenari Immobiliari ${ }^{8}$ won the tender.

The complexity of real estate portfolio and information necessary to perform the evaluation activity required periodic meetings among the parties. The first phases of research-relating to the analysis of the real estate database-highlighted the difficulty in tracing and identifying the source of the data, its accuracy and its level of updating, therefore the correctness of the data stored in relation to the condition of the asset during this analysis phase.

An in-depth knowledge of real estate portfolio is essential for the correct attribution of market value.

\section{Strategies for Optimizing Asset Profitability: From Administrative Management to a New Efficient Management Model}

The problem faced in the management of real estate portfolios such as ASP is a problem of choice: every good manager must make decisions orienting them to managerial choices to maximize added value (Ciaramella 2016).

Considering the characteristics of real estate assets of ASP, the optimization of profitability derives from two main areas: administrative and operations management (Property and Facility management) and the management model adopted. The first one requires a system of diversified skills that condition the second one. The management of rents, monitoring and containment of costs are typically property manager's activities and requires technical-administrative and commercial skills. The planning of maintenance requires technical, project and facility management skills. The adopted management model is strongly influenced by the professionalism and skills in company workforce and is attributable in part to the so-called Social Management typical of social housing interventions (Pavesi et al. 2017).

In the case of ASP' portfolio, a part of management activities is oriented to safeguarding the profitability of the assets, another part, to managing the main maintenance activities in addition to managing and providing welfare services.

Administrative activity includes management of rents and costs, with the aim to maximize net operating income and to manage new rentals for vacant spaces, with the aim to reduce vacancy rate.

\footnotetext{
${ }^{7}$ The writing of call for tender was carried out by Contracts-Service Contracts, services and supplies under the advice of $\mathrm{A}$. S. Pavesi. In this phase, the $\mathrm{ABC}$ group carried out the project management activity.

${ }^{8}$ Scenari Immobiliari I Independent Institute of Studies and Research. www.scenari-immobiliari.it.
} 
During the analysis, the analysis of the gross yield, ${ }^{9}$ of the potential yield ${ }^{10}$ as well as the analysis of the vacancy rate was evident, representing the margins of improvement in the management of the assets.

The study of vacancy has made it possible to compare available data with the results of studies on the trend of rental market in the city and for different functional types, verifying the positioning of one's portfolio with respect to market benchmark.

This comparison made it possible to set a management strategy in line with the market needs and influencing the investment choices.

In fact, the management of operations is always attributable to the whole series of maintenance activities (ordinary and extraordinary maintenance), which has the aim to maintain or improve the conservation status of buildings and consequently to maintain over time the value of the assets.

With a view to optimizing the profitability of assets and resources used, it was appropriate to reflect on the ways in which administrative management and operations (property and facility management) were carried out by ASP. The objective was to identify which management model (internal, outsourcing or mixed) could be more suitable for the Company, both in relation to the state of the art and in a perspective view of efficiency.

The analysis showed that the management model adopted was attributable to the "internal management model." The internal staff of ASP was completely dedicated to asset management (regulatory compliance, cost and expense planning, management and supervision of external suppliers, management and coordination of services provided with internal staff) and, to a small extent, operational activities (technical maintenance).

With respect to this topic, the research group analyzed and evaluated alternative management models: outsourcing management model and hybrid management model with the outsourcing of operating activities only. The first model prefigures the outsourcing of all services to a single supplier (so-called Integrated Services). This model favors economies of scale and a reduction in costs, but in the same time, determines the loss of control over the process, on quality management in the provision of services, in particular of maintenance ones.

The second model provides for the outsourcing of operational services to different suppliers and the presence of an internal function in the Company dedicated to the management of contracts, with the task of coordinating, administering, and supervising the supplies. On the one hand, this model provides for an increase in organizational flexibility and a greater ability to control service costs, and on the other, it requires considerable coordination by the staff involved in the management.

The widespread orientation to outsourcing by different groups and organizations for the management of real estate assets is essentially connected to the possibility of transforming fixed costs (employees) into variable costs (external contracts). This choice, which in many ways can be shared in its general principles, cannot, however,

\footnotetext{
${ }^{9}$ Gross Yield is calculated as the ratio among current fee, sum of MV and capex.

${ }^{10}$ Potential Yield is the return that could be obtained if all the vacant spaces were leased to market rents.
} 
disregard the vision of the owner or manager. Very often the choices of outsourcing brought unsatisfactory results; in several cases, it may be appropriate to aim at the enhancement of properties and, at the same time, of people involved in.

Based on features, real estate portfolio and ASP organization model, the "internal management model with outsourcing of operating activities" was evaluated as viable because it is capable to obtain the enhancement of the real estate assets, a better use of resources involved. The recommendation is, whatever the choice, the supervision of the information, and the governance and the control of activities were maintained by ASP.

\section{Strategies for Optimizing the ASP Management Model from a Circular and Social Economy Perspective}

The constant question that has always guided investigations and research work has been: "What does ASP need?" The collaboration between the research group and ASP has found strong bases of understanding in the intention to pursue the mission of general interest of the Company through criteria of environmental, social, and economic sustainability. The results of the research have, on the one hand, outlined the levers for making management, resources, and processes more efficient, and on the other hand, identified enhancement strategies for assets in a social and circular economy perspective, as expressed in the ASP Social Balance (2017).

The research results outline the following strategic levers for ASP:

- introduction of specialized figures in the field of Property and Asset Management and Real Estate Analyst (for business plans, feasibility studies, coordination of advisor figures, evaluation of new investments, etc.).

- Optimization of the Facility system through the investment in the field of information services for dynamic asset management, maintenance optimization, etc.

- Creation of an ASP brand through the implementation of a "smart" platform aimed at citizens, to give voice to ideas, needs, new trends and specialize services.

- Optimization of condominium management also through experimentation according to new models of urban welfare (Social management).

- Strategic management of assets through greater diversification with respect to emerging needs or new trends.

The question whether the contribution of assets to an impact finance fund could be the most effective solution to achieve these objectives has remained in the background.

The characteristics of ASP real estate portfolio allow, such as:

- the targeted alienation of some assets more suited to the market to free resources to be reinvested in the development of innovative services spread throughout the territory (social mix); 
- the targeted alienation of some assets that are more suited to the market to free up resources to be reinvested in scheduled asset maintenance.

Under these conditions, it seemed more challenging to apply the best management model from virtuous SGRs to the existing corporate structure.

In fact, ASP acts as a benefit corporation because it creates a sort of public benefit in the community in which it operates and has a concrete positive impact on people and the environment (an area that is certainly to be improved); in ASP, "the shareholders" (and the citizens themselves) can also evaluate qualitative and quantitative performances, based on declared objectives.

ASP was found to have all the features to accept the challenge of creating a model of a Public Company of excellence, able to activate forms of private-public partnership according to a welfare scheme that makes the most of its assets as a tool to create positive impacts in the areas of corporate governance, human resources, communities and the environment, through the services offered to the city of Bologna. It represents the public subject that addresses its services to the weaker groups and at the same time is able to specialize them toward more profitable areas in a dynamic cycle, thanks to the variety and size of the real estate stock it administers in respect of the legacy of those who have been able to donate to their own city.

The demonstrated ability to administer ASP with seriousness, competence, and sense of responsibility of the people who work there, together with the vision of governance, represents the virtuous case of Public Company, a best practice and a scalable model in the more general society responsible for the provision of welfare services.

\section{References}

ASP Città di Bologna. (2017). Bilancio Sociale. Available on http://www.aspbologna.it/bilanciosociale/asp-citta-di-bologna/bilancio-sociale/bilancio-sociale-2017.

Burns, C. M. (2002). Analysing the contribution of corporate real estate to the strategic competitive advantage of organisations, working papers. Available at: www.occupier.org/papers/working paper10.pd.

Ciaramella, A. (2016). Corporate Real Estate. Strategie, modelli e strumenti per la gestione attiva del patrimonio immobiliare aziendale. Milano: FrancoAngeli.

Huffman, F. E. (2003). Corporate real estate risk management and assessment. Journal of Corporate Real Estate, 5(1), 31-41.

Pavesi, A. S., Ferri, G., Zaccaria, R., Gechelin, M. (2017). Abitare Collaborativo: percorsi di coesione sociale per un nuovo welfare di comunità. TECHNE Journal of Technology for Architecture and Environment, 14 (Architettura e innovazione sociale. Firenze). 
Open Access This chapter is licensed under the terms of the Creative Commons Attribution 4.0 International License (http://creativecommons.org/licenses/by/4.0/), which permits use, sharing, adaptation, distribution and reproduction in any medium or format, as long as you give appropriate credit to the original author(s) and the source, provide a link to the Creative Commons license and indicate if changes were made.

The images or other third party material in this chapter are included in the chapter's Creative Commons license, unless indicated otherwise in a credit line to the material. If material is not included in the chapter's Creative Commons license and your intended use is not permitted by statutory regulation or exceeds the permitted use, you will need to obtain permission directly from the copyright holder.

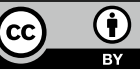

